\title{
Social economy and social entrepreneurship - the manifestation of social responsibility in the era of globalization
}

\author{
Eva Pongracz* \\ University of Economics in Bratislava, Dolnozemska cesta 1, 85235 Bratislava, Slovakia
}

\begin{abstract}
Currently, in Europe as well as in V4 countries, more and more interest is noted in the social economy. It is the answer to the socioeconomic consequences of globalization. We can consider social entrepreneurship to be a business of the future with social responsibility, which favors social mission before making a profit. It is a hybrid business model that brings innovation, promotes regional development and improves quality of life of the local population. The social entrepreneurship, with the creation of sustainable jobs, reduces unemployment, protects the environment, provides goods and services for which the state and the private sector are not interested. It applies participatory and democratic corporate governance, thereby increasing the responsibility of all stakeholders. In this paper we point out that the development of social economy and social entrepreneurship in Slovakia has its own specifics. The practice precedes the theory, which brings many problems and creates unfavourable conditions for development of social entrepreneurship. We identified weaknesses in the social economy sector and offered recommendations for practice, especially for representatives of public administration and legislators. Moreover, we consider the training of future employees, managers of social entrepreneurship, local government representatives, as well as the provision of information to the general public on this area as a key factor for the development of the concept of social economy. Information for the preparation of this paper was drawn from the laws, expert studies and economic literature.
\end{abstract}

\section{Introduction}

As a result of unfavourable demographic development, globalization processes and ongoing socioeconomic changes in our society, the number of persons threatened with social exclusion is growing; we have a significant share of long-term unemployment and ever more lonely and elderly people, while problems related to the environment are increasing. This is a series of problems that individual state policies should immediately address. A social or solidarity economy, which favours a social, societal or community goal, cooperation and solidarity over economic profit, is coming to the forefront. Social economy is considered as the option that offers the best response in times of crisis. In this

*Corresponding author: eva.pongracz@euba.sk 
context, social economy companies play an essential role in the promotion of sustainable growth[1]. In addition, coordinated development of social economic development and ecological environmental development is very necessary for sustainable development [2].

\section{Social economy and social entrepreneurship}

A social economy creates a new area for business activities that include social innovation and at the same time resolve the social issues of a community. So-called "hybrid business entities", which put achieving a social goal over the making of profit, are gradually being born [3].

The International Center of Research and Information on the Public, Social and Cooperative Economy in the summary section of the report drawn up by the European Economic and Social Committee, proposes the following definition of social economy: „It is a group of companies of a private nature organized into a formal framework, which have the freedom to decide and freedom of voluntary membership, and which are connected through market processes for the fulfillment of their needs, for the sake of production of goods, providing services, or related insurance and financing“" [4].

Social economics is a new economic discipline and a multi-disciplinary field which seeks relations and dependencies with other economic, anthropological, politico-scientific, psychological, as well as sociological theories [5]. It presents a framework for the possible functioning of the social economy, while its dimension in a particular country is determined by the respective cultural-historical and economic-political traditions [6].

Social enterprises, which combine organisational forms of profit-making businesses and charity, are manifested as an ideal type of hybrid organisation [7]. In addition, social enterprises introduce activities which combine business activities, social innovation and non-profit management [8]. In social entrepreneurship, social and economic missions coexist in a tensioned balance. At times, business survival requires reprioritizing objectives [9]. Social enterprises emerge in reaction to the new forms of social needs which neither the market nor the state can or, for some reason, are willing to satisfy. They introduce certain particularities into the classical business model for which the future managers and employees in such an initiative need to be prepared [6].

According to the method of fulfilling a social/societal goal (their primary task) we can generally divide social enterprises into three groups:

- social enterprises offering services or goods for the socially disadvantaged, vulnerable persons, marginalized groups,

- social enterprises employing persons who before being hired were disadvantages job seekers on the labour market or vulnerable persons,

- social enterprises performing their activities in the field of environmental protection.

Social entrepreneurship as an alternative way to solve social problems is rapidly becoming popular. The efficiency of this type of activity largely depends on the formal institutions operating in the territory under consideration, as well as on the prevailing values, habits, customs peculiar to social groups and which form an informal institutional environment [10].

In Slovakia, a social enterprise, specifically of the WISE (Work Integration Social Enterprises) type, was for the first time anchored in legislation in 2008 with an amendment to Act No. 5/2004 Coll. on Employment Services. In the sense of this law, a social enterprise is assigned among the instruments of an active labour market policy. It resolves the employment and employability of disadvantaged job seekers, whereby it is mandatory to use a certain share of income for the creation of new jobs or for improving working conditions. This was a significant moment as a foundation for the development of this sector. 
In addition, so-called municipal social enterprises have gradually arisen as an alternative developmental tool for a territory. These are enterprises that handle local problems with the participation of local authorities. The main goal of social responsibility of public administration is the ensuring sustainable development and ultimately the quality of life of local citizens.

Certain criteria were specified for a work integration social enterprise which is a legal entity or natural person. They employed disadvantaged job seekers and helped them find jobs on the open labour market. A condition was also reinvestment of a certain portion of income back into the enterprise. These subject had the opportunity to draw an allowance for the support of creating and maintaining jobs in a social enterprise in the first 12-24 months of doing business. The provision of these allowances was cancelled in 2013, and the drawing of other active labour market policy allowances was not tied to assigning a status. For this reason, there was no interest from business subjects that showed the signs of a social enterprise to apply for such a status, and we can consider $2013-2017$ as a period of quiet in the development of the social economy sector.

\section{The determinants of social entrepreneurship development in Slovakia}

A new comprehensive Act No. 112/2018 on the Social Economy, which defines subject, criteria, financial and non-financial support for this area and sets the conditions for creating a favourable environment for this sector, has the ambition to remedy these deficiencies.

We consider a disadvantaged person in particular to be one who has not been employed in the previous six months and has other disadvantages, or a person with a health disability. The law defines the category of vulnerable persons as, for example, a recipient of social services, a person reliant on assistance of another physical person, a person after completion of maternity leave or a parental allowance, a person drawing an old-age pension, a natural person with a low income, a person just released from prison, an asylum seeker, etc.

Through their activities, subjects of the social economy bring positive social impacts by fulfilling a public or community interest. The law defines the social economy as the "summary of productive, distributional or consumer activities performed by means of economic activities or non-economic activities independently of state authorities, the aim of which is to achieve a positive impact"[11].

A social enterprise may be a civic association, a foundation, a non-profit organisation, a specialised church facility, a trade association, a cooperative or a natural personentrepreneur. These are the legal forms of subjects that may perform economic activities, i.e. they may do business and their primary goal is achieving a measurable positive social impact. These subjects provide goods and services to vulnerable or disadvantaged groups or employ them; they use at least $50 \%$ of profits to achieve the primary goal and involve their employees in particular in the decision-making processes of the enterprise. A social impact enterprise must satisfy at least two of these conditions.

A social enterprise is an entity of the social economy that performs a systematic economic activity, employs disadvantaged or vulnerable people or provides services and goods for these groups. It uses more than half of its profits to achieve the primary goal and involve stakeholders in the administration of its economic activity.

A social enterprise may, after satisfying the legally stipulated criteria, apply for recognition as a registered social enterprise. In terms of activities, a registered social enterprise may be:

- an integration enterprise,

- social enterprise housing, 
- another registered social enterprise.

The aim of an integrated enterprise is to support the employability of disadvantaged or vulnerable persons by means of employing them, minimally in a proportion of $30 \%$ of the total number of employees. It achieves a positive social impact by employing $30 \%$ disadvantaged or $30 \%$ vulnerable persons out of the total number of employees. It may also choose a combination of these persons in a share of at least $40 \%$ of the total number of employees.

Social enterprise housing makes a positive social impact by ensuring socially beneficial rental housing, i.e. by providing housing, administration, maintenance and renovation of a housing fund for the purpose of leasing it to entitled persons.

It is very important to note that a registered social enterprise may also be a subject that has a protected workshop or a protected workplace, regardless of its legal form. A condition is, aside from employing disadvantaged or vulnerable persons (in the case of a protected workshop this condition is satisfied), the observing of other conditions determined by the law.

The new law brings support for enterprises in the broader space of the social economy, namely through investment aid and compensatory aid. Investment aid is planned to be provided for the purpose of supporting initial investment. Compensatory aid is provided if the subject of the social economy, in consequence of achieving a positive social impact, is disadvantaged versus enterprises which perform this activity with the aim of making a profit. The aid amount depends on the type of disadvantaged employee. If an integrated business manages to place its employee on the so-called "open labour market", i.e. with an employer that is not an integrated business, then it has the opportunity to request a contribution in the amount of $10 \%-40 \%$ of the gross wage of a former employee [11].

The law brings new possibilities for compensatory benefits in the case of unemployed persons with health disabilities. Since 1 May 2018 it has been possible for this purpose to place an order with an integration enterprise, in which at least $30 \%$ of employees are citizens with health disabilities. This obligation may also be fulfilled by carrying out exclusive orders in a public procurement. We consider these measures as indirect instruments for entities of the social economy.

We consider the following determinants in particular to be the stimuli for development of the social economy in Slovakia: long-term unemployment, the high number of marginalized and socially excluded persons, the inability of the state to fully solve social problems of society and the emergence of new social issues.

We consider the rise in the category of elderly as another stimulus or space for the development of the social economy in Slovakia. The aging of the population on one hand brings new social issues and on the other hand opens up opportunities for the creation of new jobs, especially in the provision of various social services. There is room for business activities to satisfy the diverse needs of an increasingly large group of elderly consumers. In addition, we still perceive active older people as an untapped potential that can be engaged in the initiatives of various social enterprises.

Worsened social conditions lead to a number of problems, which third sector organizations and businesses are involved in solving to an increasingly greater measure. Third sector actors come with innovative opportunities for meeting new social needs; opportunities are opening up for them to conduct business activities as a means of ensuring their financial sustainability (declining financial support for the third sector organizations). Entrepreneurs in the private sector are expected to increase social responsibility (e.g. socially responsible entrepreneurship), build partnerships, particularly in community development, which may be beneficial not only for the entrepreneurs but will also have a positive impact on the life of the entire community. 


\section{Conclusion}

Social entrepreneurship is seen as differing from other forms of entrepreneurship in the relatively higher priority given to promoting social value and development versus capturing economic value [12]. It is a precarious activity that must always strike a delicate balance between commercial principles and social concerns [13]. Social enterprises are organizations that try to reconcile the often competitive economic and social missions, by developing hybrid projects that produce both economic and social value. Nonetheless, the sustainability of those initiatives seems often at stake, due to market pressures [14].

Creating an enabling environment for social entrepreneurship in tackling complex socio-economic challenges is at the forefront of government policy agendas globally [15]. The strategic aim of the social economy sector is to achieve social recognition for its subjects and to gain a level of quality for the services and products it offers. Through their activities they disburden the state, resolve societal, community and social problems, and they deserve support and society-wide attention.

This paper is an output of the science project of the Scientific Grant Agency (VEGA) 1/0367/17 „Economic, legislative and institutional preconditions and perspectives of social and solidarity economy in the V4 countries in relation to the promotion of social inclusion".

\section{References}

1. D. Palacios-Marques, M.G. Garcia, M.M. Sanchez, M.P.A. Mari, Social entrepreneurship and organizational performance: A study of the mediating role of distinctive competencies in marketing. Journal of Business Research, 101, 426-432 (2019)

2. Y. Fan, Ch. Fang, Q. Zhang, Coupling coordinated development between social economy and ecological environment in Chinese provincial capital cities-assessment and policy implications. Journal of Cleaner Production, 229, 289-298 (2019)

3. P. Sika at al., Socialna politika. (Vydavatelstvo Ekonom, Bratislava, 2018)

4. CIRIEC. The social economy in the European Union: A summary report drafted by CIRIEC for the European Economic and Social Committee. (2007)

5. M. Dohnalova. Socialni ekonomika v evropskem kontextu. (CERM, Brno, 2006)

6. E. Pongracz, T. Kollariková. Situation of young people in the Slovak labor market and possibilities of their placement in the area of social economy. Hospodarska politika $v$ clenskych zemich Evropske unie: recenzovany sbornik prispěvku XII. Mezionarodni vedecké konference. Opava, Czech Republic, $762-771$ (2014)

7. J. Battilana, M. Lee, Advancing research on hybrid organizing - Insights from the study of social enterprises. Academy of Management Annals, 8, 397-441 (2014)

8. M. Dacin, P. Dacin, P. Tracey, Social entrepreneurship: A critique and future directions. Organization Science, 22, 1203-1213 (2011)

9. P. Munoz, J. Kimmitt, Social mission as competitive advantage: A configurational analysis of the strategic conditions of social entrepreneurship. Journal of Business Research, 101, 854-861 (2019)

10. E. Popov, A. Veretennikova, A. Yu, K. M. Kozinskaya, Non-formal institutional environment of social entrepreneurship. Ekonomicheskie $i$ Sotsialnye Peremeny, 58, 217-234A (2018)

11. Act No. 112/2018 on the social economy and social enterprises - SK (2018) 
12. J. Mair, I. Marti, Social entrepreneurship research: A source of explanation, prediction, and delight. Journal of world business, 41, 36-44 (2006).

13. E. Lamy, How to make social entrepreneurship sustainable? A diagnosis and a few elements of a response. Journal of Business Ethics, 155, 645-662 (2019)

14. G. Chatzichristos, N. Nagopoulos, Institutionalizing social entrepreneurship: A path to holistic sustainability. Economic and Social Development: Book of Proceedings, 116125 (2019).

15. CH. Chan, C.H-K. Chui, K.S.T. Chan, P.S.F. Yip, The role of the social innovation and entrepreneurship development fund in fostering social entrepreneurship in Hong Kong: A study on public policy innovation. Social Policy \& Administration, 53, 903-919 (2019) 